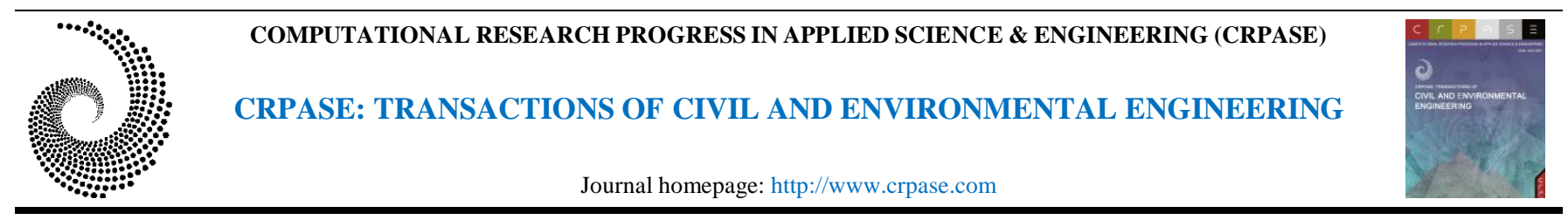

CRPASE: Transactions of Civil and Environmental Engineering 7 (4) Article ID: 2418, 1-10, December 2021

ISSN 2423-4591

Research Article

\title{
Determination of EMF Pollution in the Context of Urban Health: The Case of Safranbolu
}

\author{
Caner Yetiş ${ }^{1}$, Merve Tuna Kayili ${ }^{2 *}$ \\ ${ }^{1}$ Institue of Graduate Sciences, Karabuk University, Karabuk, Turkey \\ ${ }^{2}$ Department of Architecture, Karabuk University, Safranbolu, Karabuk, Turkey
}

\begin{tabular}{|c|c|}
\hline Keywords & Abstract \\
\hline $\begin{array}{l}\text { Electromagnetic field } \\
\text { pollution, } \\
\text { Urban health, } \\
\text { Safranbolu, } \\
\text { Historical environment. }\end{array}$ & $\begin{array}{l}\text { Significant developments in communication technologies are occurring day by day in the } \\
\text { modern world. However, electromagnetic waves emitted by base stations emerging as a } \\
\text { result of these developments and the resulting electromagnetic fields have effects on human } \\
\text { health. International institutions are also agreeing that in case of exposure to base stations } \\
\text { below a certain distance, human health, biotic populations, and buildings will be adversely } \\
\text { affected. In this study, the electromagnetic field intensity in Safranbolu, a historical city in } \\
\text { Turkey was determined and mapped on the city scale. In the context of the study, } 4 \text { base } \\
\text { stations were considered at five different distances: } 20 \mathrm{~m}, 50 \mathrm{~m}, 100 \mathrm{~m}, 200 \mathrm{~m} \text {, and } 500 \mathrm{~m} \text {. As } \\
\text { a result of the total electromagnetic field measurements made in the frequency range of } 50 \\
\mathrm{MHz} \text { and } 3.5 \mathrm{GHz} \text {, it was found that there was a decrease in the electric field at each base } \\
\text { station inversely proportional to the distance. The study is the only one that deals with } \\
\text { electric field pollution in Safranbolu, and it is expected that this study will create a basis for } \\
\text { future studies in terms of measurements to be made after the arrival of the } 5 \mathrm{G} \text { application to } \\
\text { the city. }\end{array}$ \\
\hline
\end{tabular}

\section{Introduction}

Technological devices occupy an important place in today's world, which is characterized as the information age, and many of these devices emit electromagnetic waves [1-4]. Electromagnetic field (EMF) can be defined as the push or pull force created by the charged particles consisting of electric field and magnetic field. The energy dissipation occurring as a result of the action of pushing or pulling forces is called electromagnetic radiation or electromagnetic wave propagation [5]. These waves can be emitted from two different sources, natural and artificial [6]. Electromagnetic fields originating from natural sources usually do not have a negative effect on human health. However, electromagnetic waves emitted from artificial sources stand out as a source of pollution that may cause serious problems on living beings if not handled in a controlled manner [7-9].

Along with the developing technology, the increase in the use of devices emitting electromagnetic waves also increases the exposure to these waves. Although the effects of this exposure on living beings depend on the frequency, power, and intensity of electromagnetic waves, they also differ depending on the distance of the exposed location, the duration of exposure, and the personal characteristics of the individuals $[10,11]$. When the effect of the specified technical and environmental parameters are considered, it can be said that the regulations on the subject require an interdisciplinary study. For this reason, to reveal the level of electromagnetic pollution and to determine the standards, the United International Non-Ionizing Radiation Committee

${ }^{*}$ Corresponding Author: Merve Tuna Kayili

E-mail address: mervetunakayili@karabuk.edu.tr

Received: 13 December 2021; Revised: 22 December 2021; Accepted: 27 December 2021

https://doi.org/10.52547/crpase.7.4.2418

Academic Editor: Vahid Najafi Moghadam Gilani

\footnotetext{
Please cite this article as: C. Yetiş, M. T. Kayili, Determination of EMF Pollution in the Context of Urban Health: The Case of Safranbolu, Computational Research Progress in Applied Science \& Engineering, CRPASE: Transactions of Civil and Environmental Engineering 7 (2021) 1-10, Article ID: 2418.
} 
(INIRC), the United Nations Environmental Protection Agency (UNEP), the International Commission on NonIonizing Radiation Protection (ICNIRP), and the International Labor Organization (ILO) carry out joint studies related to the subject. However, considering the different urban planning, climatic characteristics, and demographic data, it is seen that each country sets its own standards. In Turkey, the Information Technologies and Communications Institute (ITCI) conducts studies related to the electromagnetic field.

Many studies on the subject have shown that there are negative relationships between exposure to electromagnetic fields and human health $[12,13]$. Some studies have revealed that some problems such as fatigue, sleepiness, and headache may occur in short-term exposures [14,15], while some studies have proven that long-term exposures have negative effects such as brain cancer, leukemia, Alzheimer's disease, and reduced birth rate [16-24].

Electromagnetic fields encountered in daily life consist of two separate frequency bands. The first of these is called the ELF band and characterized as very low-frequency areas that form the areas below $2 \mathrm{kHz}$. The second is electromagnetic fields created by remote communication devices such as telephone, computer, radio, television, wireless network connections, and base stations covering from $100 \mathrm{kHz}$ to $300 \mathrm{GHz}$. These areas are called the RFMW band [12, 25-29]. Especially after the 2000s, many steps taken worldwide in order to expand the infrastructure of wireless devices and optimize network connections for ensuring fast, secure, and uninterrupted communication opportunities have been in the RF-MW band. The electromagnetic fields resulting from the studies carried out for these steps have had a certain level. It is known that if an electromagnetic field exceeds the level, it poses a risk.

With the increase in wireless network access, base stations with wide coverage areas have been started to be built in order to provide uninterrupted and fast access throughout the world. In parallel with the requirements of developing communication systems, the number of these base stations and frequency intensities are also increasing [30]. According to the data of the Ministry of Transport (2019), the total number of base stations in Turkey is 187,808 , and this number shows that there is 1 base station for every 450 people. The increase in the number of base stations makes it important to determine and map the level of electromagnetic pollution on an urban scale [31-32]. As a result of the need for new settlement areas, cities are growing in an unplanned way, especially in cities that receive intensive immigration. For this reason, many base stations remain in urban living areas, and the designated safety distance can be exceeded. This level of electromagnetic pollution, which develops on an urban scale, can create risks on a regional scale depending on the location of the base stations in the city. Therefore, mapping electromagnetic fields in cities and examining the safety distances are important for public health. Although there are many urbanscale studies conducted to detect the electromagnetic field [33-41] and although there are also data indicating that old buildings in a historical center may be more affected by the electromagnetic field [42], there is no study focusing on a historical center in the literature.
Within the scope of this study, the electromagnetic field pollution level of Safranbolu city, which is included in the UNESCO World Heritage Cities List, was determined by measurements, and an electromagnetic map of the city was created. The safety distances of the base stations and the conformity of the structural approaches to the safety distances were examined. The study is the first electromagnetic study conducted on an urban scale in a historical center. The study is expected to raise awareness about electromagnetic pollution, provide the basis for measurements to be made after the arrival of $5 \mathrm{G}$ in the city, and shed light on future studies to be conducted in protected cities.

\section{Material and Method}

\subsection{Case Study}

The city of Safranbolu is a district of Karabuk province located at latitude 41.2636 and longitude 32.6951 (Figure 1a,b). Safranbolu, with a central population of 51,904 , has a residential area of $9.73 \mathrm{~km}^{2}$. The city, which is famous for its historical Safranbolu houses reflecting the classical Ottoman urban architecture, is one of Turkey's 9 cultural assets listed on the World Heritage List since 17 December 1994 and attracts touristic interest thanks to this feature (Figure 1c). As can be seen in Figure 2, in the context of this study, 4 base stations (BS-1, BS-2, BS-3, BS-4), located in different regions, were identified in the residential area. These base stations are located close to the border points of the city campuses. BS-1 and BS-3 are within urban residential areas, while BS-2 and BS-4 are relatively far from residential areas (Figure 3).

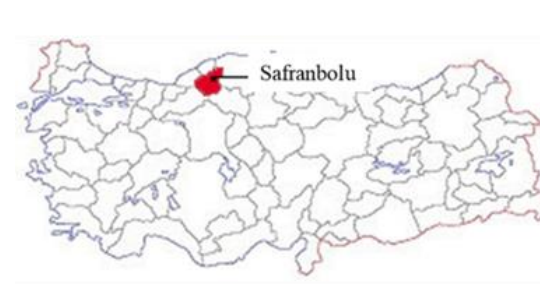

a

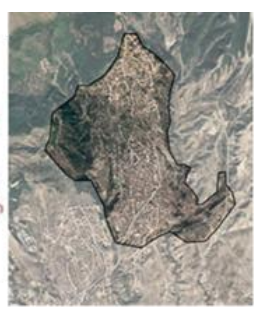

b

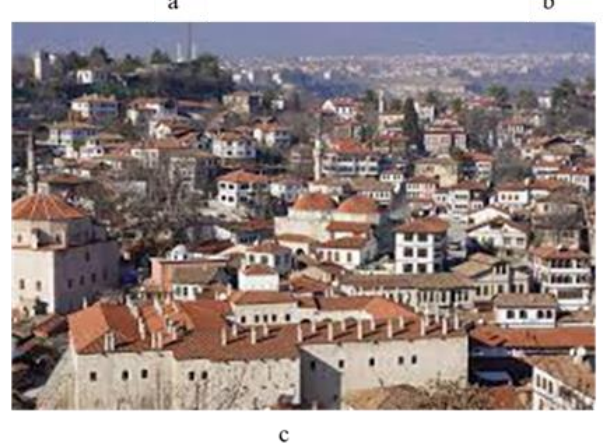

Figure 1. a) The location of Safranbolu on the map of Turkey, b) Safranbolu settlement borders, c) Safranbolu old city

\subsection{Electromagnetic Field (EMF) Measurements}

The propagation of electromagnetic waves varies depending on various parameters such as ambient temperature, humidity, frequency of communication, and the nature of the base station [30]. Therefore, there are 
measurement rules determined by national and international institutions. In this study, the measurement rules were determined based on the Electronic Communication Devices Security Certificate Regulation published by the Turkey Information Technology Institution (ITCI) in 2011. According to Article 15 of this regulation;

1. Electric and magnetic fields will be measured separately in measurements to be made with broadband devices.

2. At points where there is more than one transmitter, all electric field strength will be measured.

3. Any electronic device that is likely to be on the person who will make the measurement should be turned off.

4. The minimum duration of the measurements is 1 minute, and measurements should be made at a height of at least 1.5 meters above the ground.

5. Depending on the antenna direction, measurements should be taken from the nearest three accessible points outside the safe distance [1].

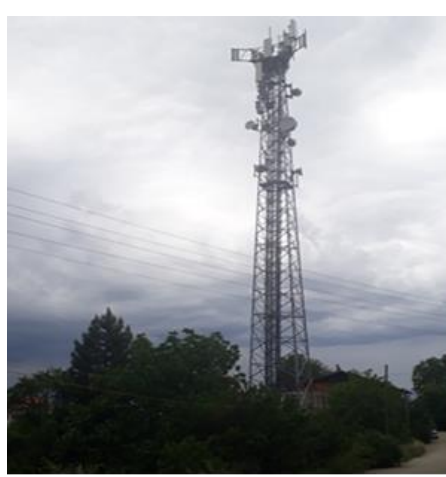

BS-1 Esentepe District

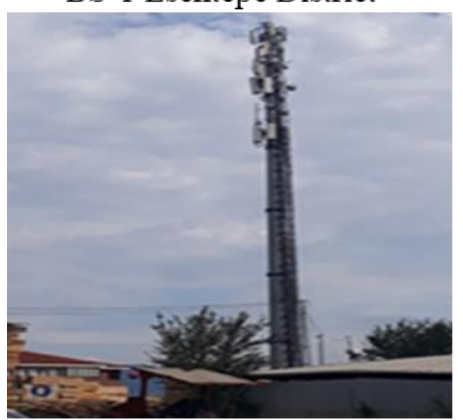

BS-3 Barış District

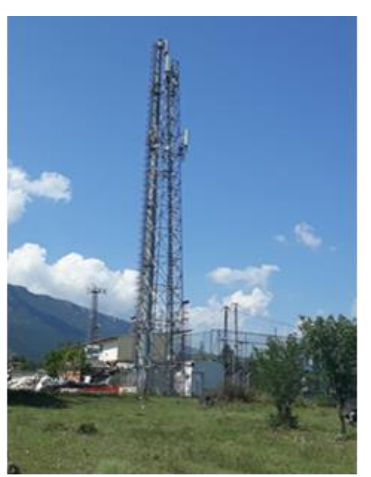

BS-2 Bulak District

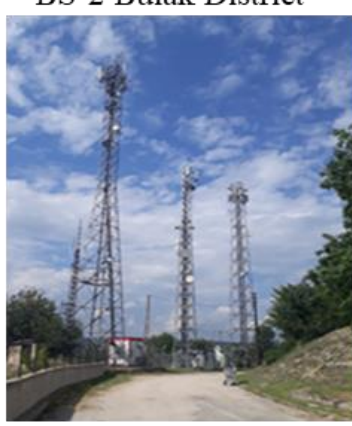

BS-4 Babasultan District
Figure 2. Base stations and their views

In this study, Extech 3.5 GHz EMF Meter was used for electric field measurements and PCE-EMF823 (Fig 4a, b) device was used for magnetic field measurements. Technical information of the devices is given in Table I. Since there is no standard developed in this direction, measurement points and distances were determined based on the related literature [43-46]. The security distances around the detected 4 base stations were considered at five different distances: $20 \mathrm{~m}$, $50 \mathrm{~m}, 100 \mathrm{~m}, 200 \mathrm{~m}$, and $500 \mathrm{~m}$, respectively (Fig 4c). To be able to minimize the margin of error in these regions, 4 different measurement points were determined in each of them. In these areas, the total electromagnetic field value was measured for each point in the frequency range from $50 \mathrm{MHz}$ to $3.5 \mathrm{GHz}$. In addition, taking into account the Information Technologies and Communication Institute regulation, measurements were made by distinguishing between the frequencies of $900 \mathrm{MHz}$ and $1800 \mathrm{MHz}$ at base station areas 1 and 3, where there is only one base station in each of them. Since there is more than one base station in areas 2 and 4 , the total electromagnetic field strength in these areas was taken into account.

The average value is important during the measurement period. According to the Information Technologies and Communication Institute, Turkey (ITCI) regulation, the minimum measurement time is 1 minute. However, to be able to ensure data reliability, measurements were taken for 6 minutes instead of 1 minute based on the ICNIRP guideline. Measurements were carried out for 24 days between 31 May 2021 and 26 June 2021. Measurements were taken from 80 different points per day, including 20 points for each base station. A total of 1920 measurements were made during the study period, and these measurement values were evaluated based on the limit values determined by the ITCI and ICNIRP guidelines. Threshold limit values determined by these institutions are given in Table II.

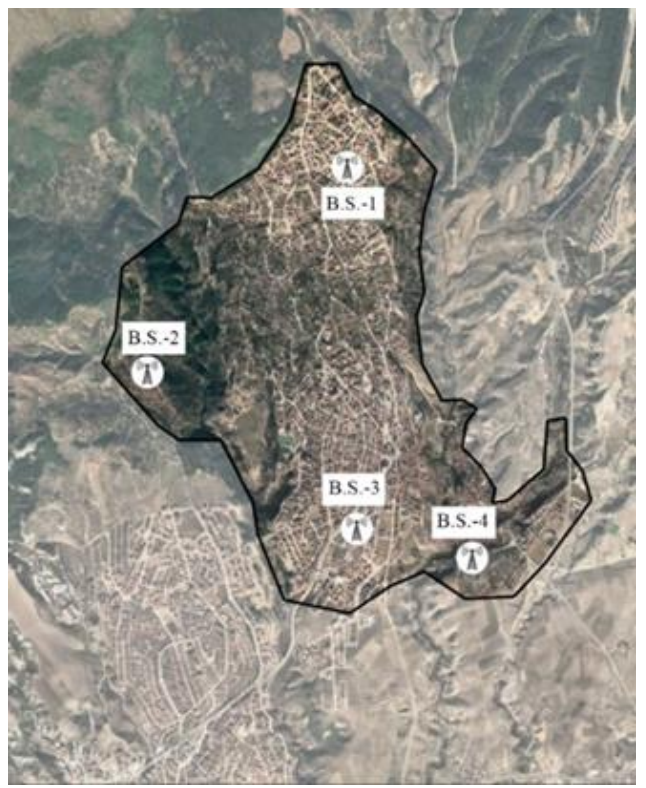

Figure 3. Locations of base stations

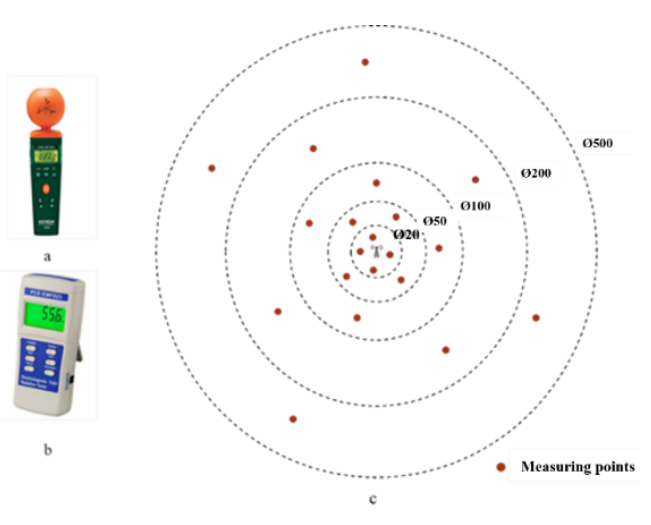

Figure 4. a) Extech $3.5 \mathrm{GHz}$ EMF Meter electric field meter b) PCE-EMF823 magnetic field meter c) Measuring zones and measuring points 
Table 1. Technical information of measuring equipment

\begin{tabular}{|c|c|c|c|c|c|}
\hline \multirow[t]{2}{*}{ Equipment } & \multicolumn{5}{|c|}{ Features } \\
\hline & Measuring range & Unit & Measuring range & Frequency range & Measuring range \\
\hline $\begin{array}{c}\text { Extech } 3.5 \mathrm{GHz} \\
\text { EMF Meter }\end{array}$ & $20 \mathrm{mV} / \mathrm{m}-108 \mathrm{~V} / \mathrm{m}$ & $\begin{array}{c}\mathrm{mV} / \mathrm{m}, \mathrm{V} / \mathrm{m}, \mu \mathrm{A} / \mathrm{m}, \\
\mathrm{mA} / \mathrm{m}, \mu \mathrm{W} / \mathrm{m}^{2}, \\
\mathrm{~mW} / \mathrm{m}^{2}, \mathrm{~W} / \mathrm{m}^{2}, \\
\mu \mathrm{W} / \mathrm{cm}^{2}, \mathrm{~mW} / \mathrm{cm}^{2}\end{array}$ & $\begin{array}{c}0.1 \mathrm{mVm}, 0.1 \mathrm{~mA} / \mathrm{m} \\
0.1 \mathrm{~mW} / \mathrm{m}^{2} \\
0.001 \mathrm{~mW} / \mathrm{cm}^{2}\end{array}$ & $\begin{array}{c}\text { 50MHz to } 3.5 \mathrm{GHz} \\
\text { (Measurement } \\
\text { optimized for } \\
900 \mathrm{MHz}, 1800 \mathrm{MHz} \\
\text { and } 2.7 \mathrm{GHz} \text { ) }\end{array}$ & $1 \mathrm{sec}$ \\
\hline PCE-EMF823 & $\begin{array}{c}20 \mu \mathrm{T} \times 0,01 \mu \mathrm{T} / \\
200 \mu \mathrm{T} \times 0,1 \mu \mathrm{T} / \\
2000 \mu \mathrm{T} \times 1 \mu \mathrm{T}(1 \\
\mu \mathrm{T}=10 \mathrm{mGs}) \\
200 \mathrm{mGs} \times 0,1 \mathrm{mGs} \\
/ 2000 \mathrm{mGs} \times 1 \\
\mathrm{mGs} / \\
20000 \mathrm{mGs} \times 10 \\
\mathrm{mGs}\end{array}$ & $\begin{array}{c}\text { Gauss }(\mathrm{mG}) \\
\text { Tesla }(\mu \mathrm{T})\end{array}$ & $\begin{array}{c}0.01 \mu \mathrm{T} \\
\text { (until } 20 \mu \mathrm{T} \text { ) } \\
0.1 \mu \mathrm{T} \\
\text { (until } 200 \mu \mathrm{T} \text { ) } \\
1 \mu \mathrm{T} \\
\text { (until } 2000 \mu \mathrm{T} \text { ) }\end{array}$ & $30 \mathrm{~Hz}-300 \mathrm{~Hz}$ & $1 \mathrm{sec}$ \\
\hline
\end{tabular}

Table 2. Threshold limit values determined by ITCI and ICNIRP [1]

\begin{tabular}{cccc}
\hline Institutions & $\begin{array}{c}\text { Threshold limit value for } \\
900 \mathrm{MHz}(\mathrm{V} / \mathrm{m})\end{array}$ & $\begin{array}{c}\text { Threshold limit value for } \\
1800 \mathrm{MHz}(\mathrm{V} / \mathrm{m})\end{array}$ & $\begin{array}{c}\text { Threshold limit value in areas } \\
\text { with multiple base stations } \\
(\mathrm{V} / \mathrm{m})\end{array}$ \\
\hline $\begin{array}{c}\text { Information Technologies and } \\
\text { Communication Institute (ITCI/Turkey) }\end{array}$ & 10.23 & 14.47 & 30.75 \\
\hline $\begin{array}{c}\text { International Commission on Non- } \\
\text { Ionizing Radiation Protection (ICNIRP) }\end{array}$ & 41.25 & 58.33 & 41 \\
\hline
\end{tabular}

\subsection{Mapping}

In addition to determining the level of electromagnetic pollution at an urban scale, it is also important to map and identify areas that may be risky. Therefore, mapping is frequently used in urban-scale electromagnetic pollution studies [47-50].

In general, the ArcGIS program is used to create pollution maps. ArcGIS is a Geographic Information Systems (GIS) software that enables the processing and analysis of software, hardware, and data components by various methods in master plans to be created for the solution of social and environmental problems on earth. The software provides efficiency by processing a lot of data within this working systematic, accelerating the information flow, and increasing the workforce [51-55]. The software is actively used by many public institutions and organizations such as municipalities, regional traffic administrations, and agriculture directorates. Considering its features, it was very important to use the analysis and visualization features of the ArcGIS software within the scope of this study. Therefore, ArcGIS and ArcScene 10.4.1 were used in the study.

\section{Results}

\section{Stations}

3.1. EMF Results Obtained in Areas with Multiple Base

It was found that the total electromagnetic field measurements made in the frequency range of $50 \mathrm{MHz}$ and $3.5 \mathrm{GHz}$ at four different base stations showed a decrease in the electric field at each base station inversely proportional to the distance. Because intensity of the electric field in volts per meter $(\mathrm{V} / \mathrm{m})$ is expressed as. This density decreases rapidly as distance increases [56]. As can be seen in Table 3, in $20 \mathrm{~m}$, the highest measurement value was determined at the BS-4 base station with $10.897 \mathrm{~V} / \mathrm{m}$, and the lowest measurement value was at the BS-3 base station with 4.023 $\mathrm{V} / \mathrm{m}$. The mean electric field intensities at the stations were listed as BS-4 > BS-1 > BS-2 > BS-3 in $20 \mathrm{~m}$. In $500 \mathrm{~m}$, the highest measurement value was found at the BS-4 base station with $2.361 \mathrm{~V} / \mathrm{m}$, while the lowest measurement value was found at the BS-3 base station with $1.333 \mathrm{~V} / \mathrm{m}$. The mean electric field intensities at the stations were listed in $500 \mathrm{~m}$ as BS-4 > BS-1 > BS-3 > BS-2.

The urban pollution map created by considering the average measurement values is given in Figure 5. As a result of the measurements, no data on the magnetic field was found. Based on ITCI and ICNIRP, considering the compliance of the measurement results with the limit values, the total electromagnetic field limit values were determined if there were more than one base station at a point. Depending on this data, the suitability of the total electromagnetic field limit values at BS-2 and BS-4 base stations was examined within the scope of the study, and it was determined that the electromagnetic field was below the limit values determined by ITCI $(30.75 \mathrm{~V} / \mathrm{m})$ and ICNIRP $(41 \mathrm{~V} / \mathrm{m})$ (Table 2). Total EF graphs and regional pollution maps made in the $50 \mathrm{MHz}$ to $3.5 \mathrm{GHz}$ frequency range presented in Table 4. 
Table 3. Total EF results in the frequency range of $50 \mathrm{MHz}$ to $3.5 \mathrm{GHz}$

\begin{tabular}{cccccc}
\hline Base Stations & $20 \mathrm{~m}(\mathrm{~V} / \mathrm{m})$ & $50 \mathrm{~m}(\mathrm{~V} / \mathrm{m})$ & $100 \mathrm{~m}(\mathrm{~V} / \mathrm{m})$ & $200 \mathrm{~m}(\mathrm{~V} / \mathrm{m})$ & $500 \mathrm{~m}(\mathrm{~V} / \mathrm{m})$ \\
\hline BS-1 (max) & 9.987 & 7.787 & 4.236 & 2.142 & 1.126 \\
BS-1 (mean) & 6.645 & 5.755 & 3.156 & 1.001 & 1.356 \\
BS-1 (min) & 5.554 & 4.123 & 2.102 & 1.058 & 0.086 \\
BS-2 (max) & 8.255 & 5.132 & 3.438 & 1.017 & 0.526 \\
BS-2 (mean) & 6.456 & 4.896 & 2.458 & 2.652 & 0.458 \\
BS-2 (min) & 5.103 & 3.454 & 4.259 & 2.897 & 0.185 \\
BS-3 (max) & 8.999 & 6.125 & 2.524 & 1.217 & 0.658 \\
BS-3 (mean) & 5.836 & 4.321 & 2.699 & 3.995 & 0.369 \\
BS-3 (min) & 4.023 & 3.458 & 4.156 & 2.999 & 2.361 \\
BS-4 (max) & 10.897 & 8.147 & 3.545 & 2.566 & 1.841 \\
BS-4 (mean) & 7.569 & 6.454 & 3.896 & & 1.589 \\
BS-4 (min) & 6.127 & 5.221 & &
\end{tabular}

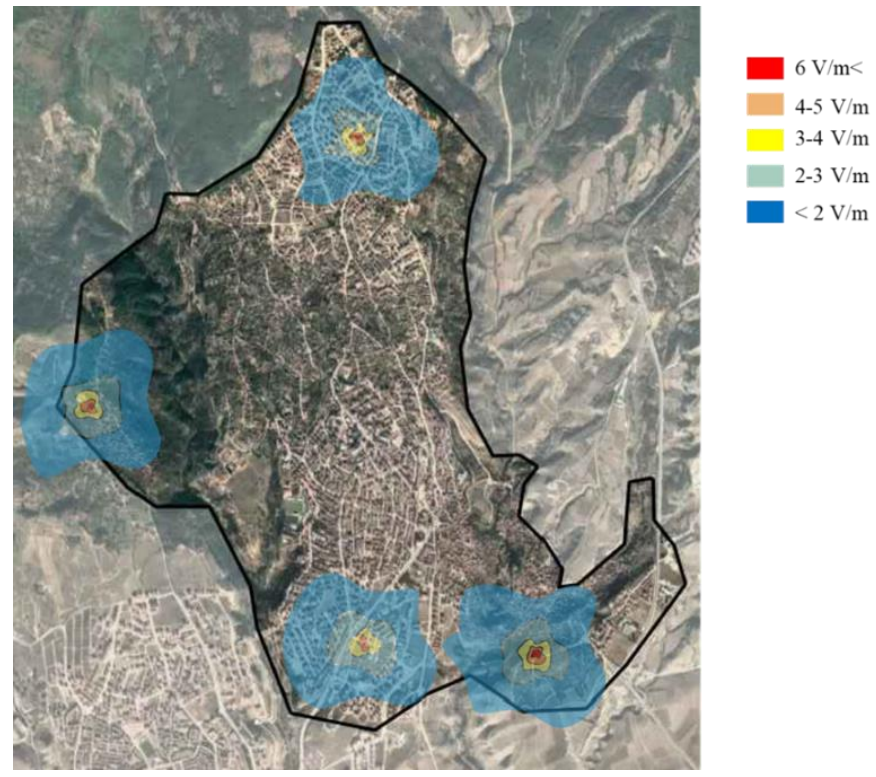

Figure 5. Total EF pollution map of Safranbolu

Table 4. Total EF graphs and regional pollution maps made in the $50 \mathrm{MHz}$ to $3.5 \mathrm{GHz}$ frequency range

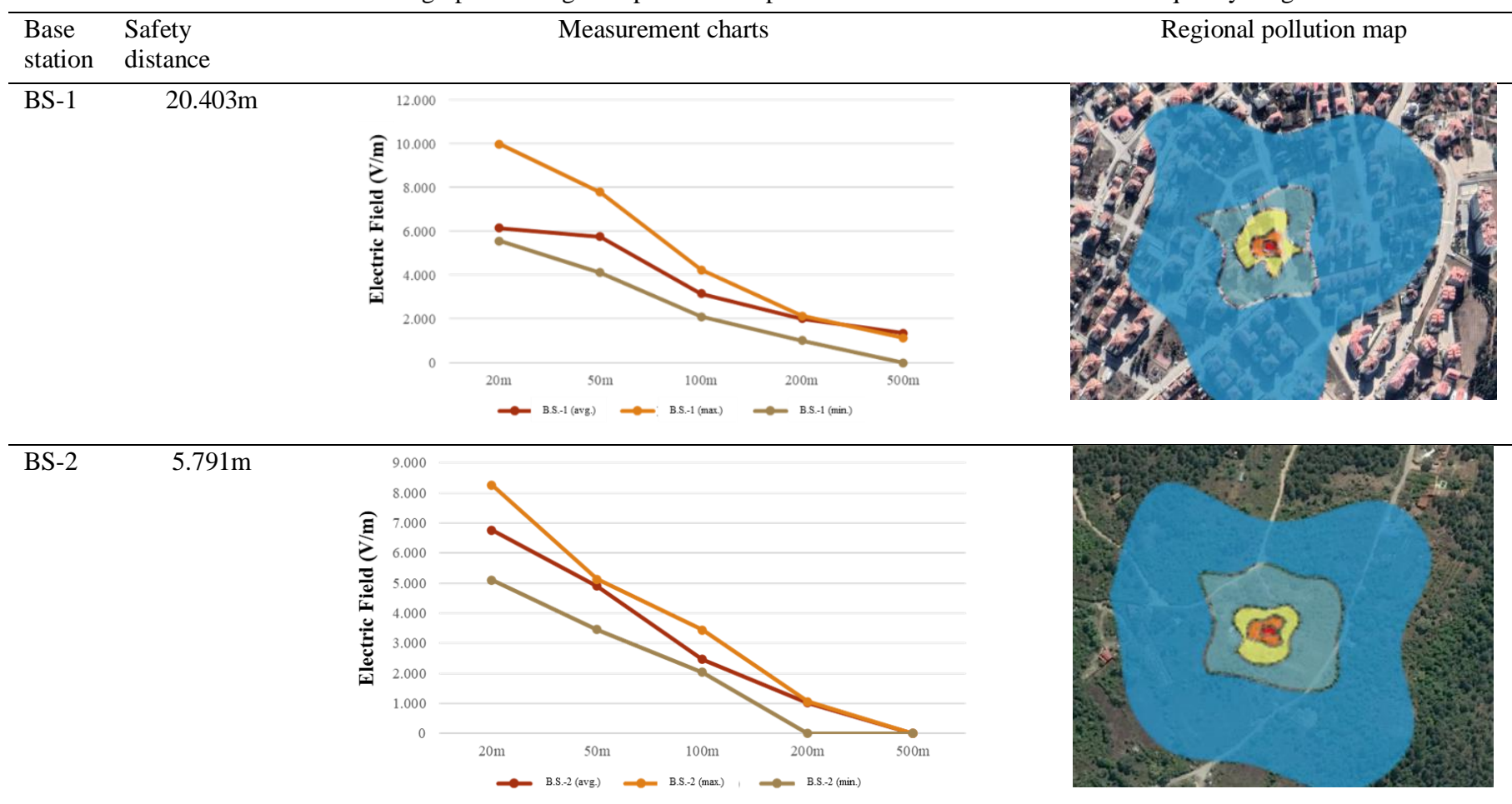




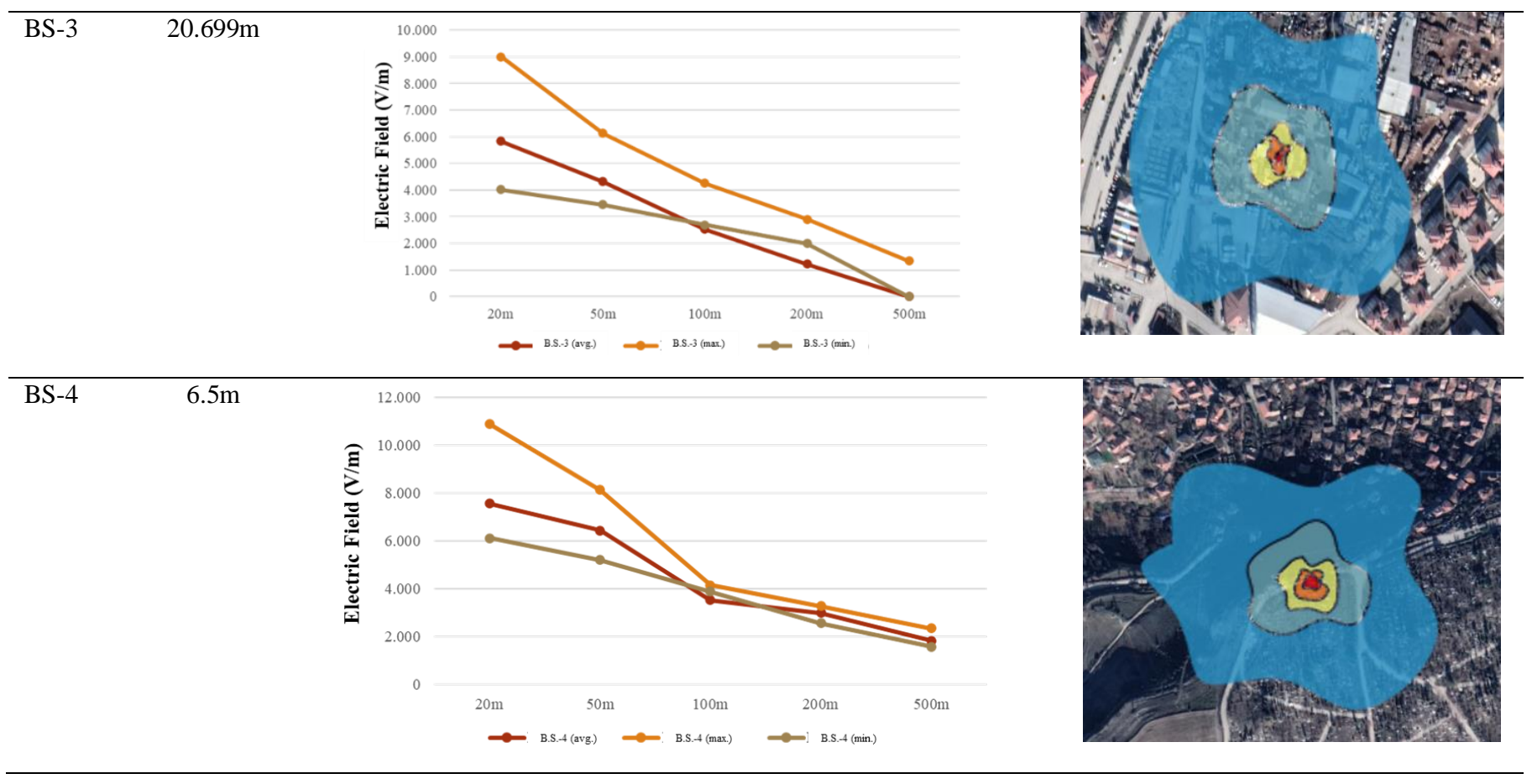

3.2. EMF results in the $900 \mathrm{MHz}$ and $1800 \mathrm{MHz}$ Frequency Range

Measurements made on a broadband scale are obtained by summing the measurement values on the $\mathrm{x}, \mathrm{y}$, and $\mathrm{z}$ axes into a single value. Due to the problems that might arise if this measurement system did not classify different frequency ranges and compare them with limit values, measurements at BS- 1 and BS-3 base stations were carried out in $900 \mathrm{MHz}$ and $1800 \mathrm{MHz}$ frequency bands.

When the measurements made at the BS-1 base station were examined, it was determined that the electromagnetic field intensity at the frequency of $1800 \mathrm{MHz}$ was higher than that of the $900 \mathrm{MHz}$ frequency band. In measurements made at $900 \mathrm{MHz}$ frequency, the maximum value was $7.125 \mathrm{~V} / \mathrm{m}$ between $20 \mathrm{~m}$ and $500 \mathrm{~m}$, and the minimum value was 0.236 $\mathrm{V} / \mathrm{m}$; and these maximum and minimum values were determined as $8.325 \mathrm{~V} / \mathrm{m}$ and $0.369 \mathrm{~V} / \mathrm{m}$ at $1800 \mathrm{MHz}$ frequency, respectively (Table 5). Considering the threshold limit values determined by Information Technologies and Communication Institue, Turkey (ITCI) (900MHz: 10.23 V/m, 1800MHz: $14.47 \mathrm{~V} / \mathrm{m}$ ) and ICNIRP (900MHz: 41.25 $\mathrm{V} / \mathrm{m}, 1800 \mathrm{MHz}: 58.33 \mathrm{~V} / \mathrm{m})$, it was observed that the threshold limit values were not exceeded in both frequency bands (Figure 6a, b). The electromagnetic field pollution map of the frequency bands is given in Figure 7.

Table 5. EF results for BS-1 base station between $900 \mathrm{MHz}$ and $1800 \mathrm{MHz}$ frequencies

\begin{tabular}{lllllll}
\hline Frequency & Base station & $20 \mathrm{~m}(\mathrm{~V} / \mathrm{m})$ & $50 \mathrm{~m}(\mathrm{~V} / \mathrm{m})$ & $100 \mathrm{~m}(\mathrm{~V} / \mathrm{m})$ & $200 \mathrm{~m}(\mathrm{~V} / \mathrm{m})$ & $500 \mathrm{~m}(\mathrm{~V} / \mathrm{m})$ \\
\hline \multirow{3}{*}{$900 \mathrm{MHz}(\mathrm{V} / \mathrm{m})$} & BS-1 (max) & 7.125 & 5.560 & 3.313 & 1.635 & 0.963 \\
\cline { 2 - 7 } & BS-1 (mean) & 5.879 & 4.745 & 2.963 & 1.456 & 0.555 \\
\cline { 2 - 7 } & BS-1 (min) & 4.231 & 3.589 & 2.523 & 1.089 & 0.236 \\
\hline \multirow{3}{*}{$1800 \mathrm{MHz}(\mathrm{V} / \mathrm{m})$} & BS-1 (max) & 8.325 & 5.369 & 3.258 & 1.088 & 0.996 \\
& BS-1 (mean) & 6.014 & 4.896 & 2.996 & 0.875 & 0.741 \\
\cline { 2 - 7 } & BS-1 (min) & 4.601 & 3.222 & 2.631 & 0.658 & 0.369 \\
\hline
\end{tabular}
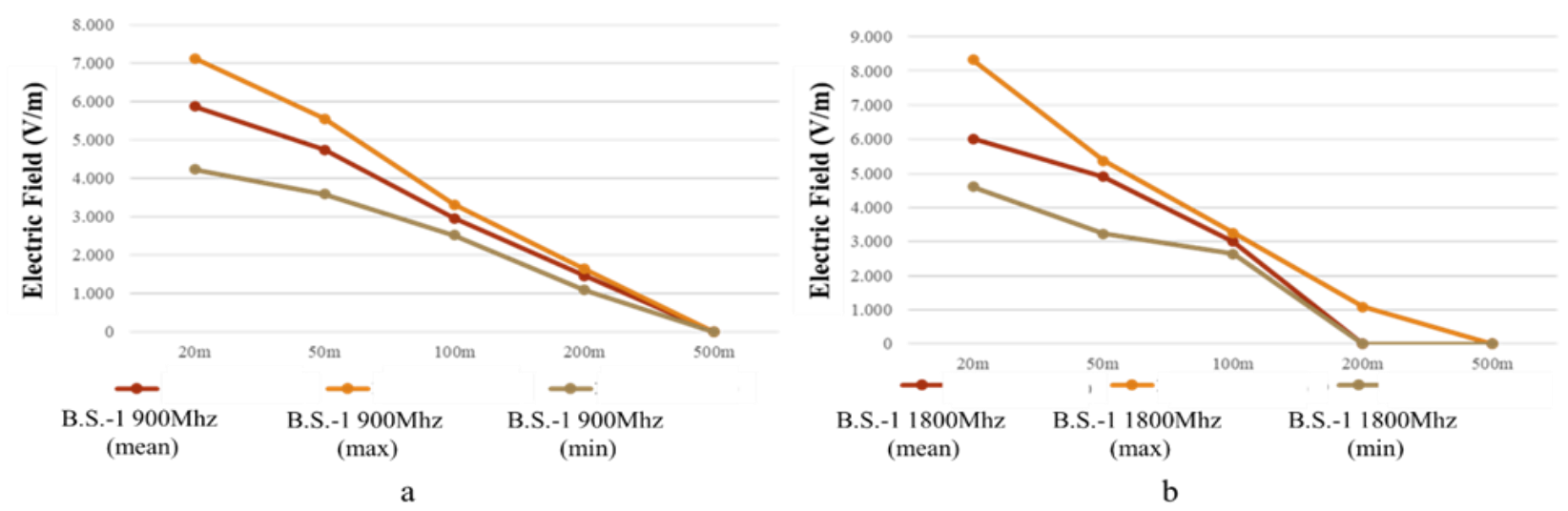

Figure 6. a) BS-1 EF results in $900 \mathrm{MHz}$ frequency b) BS-1 EF results in $1800 \mathrm{MHz}$ frequency 


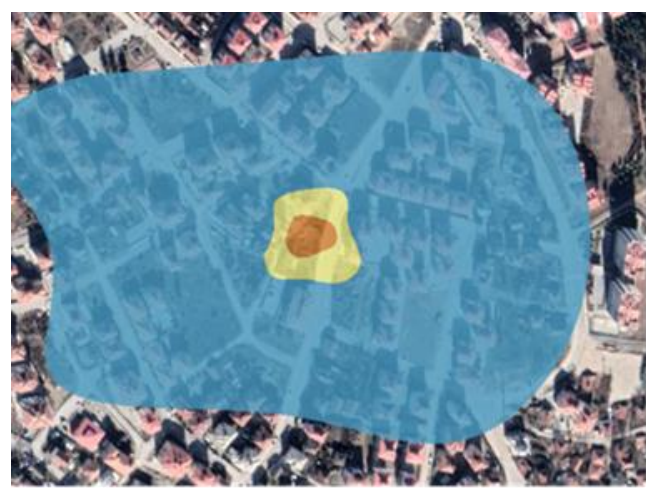

a

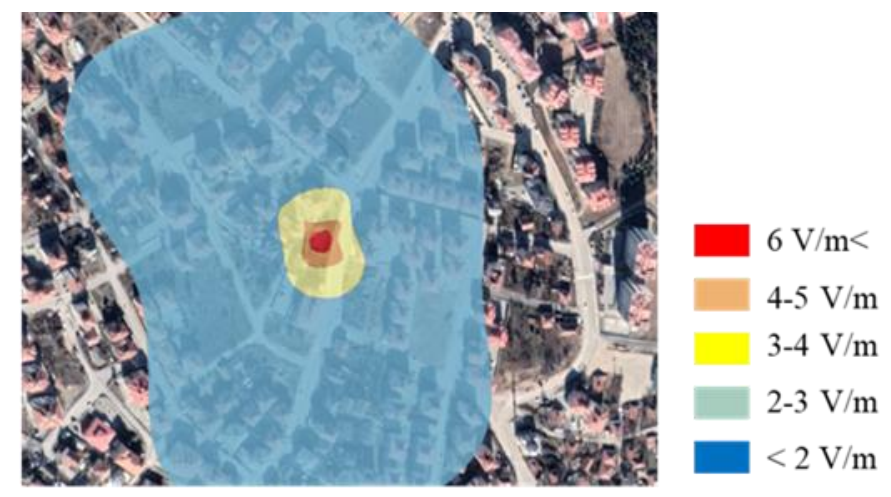

$\mathrm{b}$

Figure 7. a) BS-1 $900 \mathrm{MHz}$ frequency EMF map, b) BS-1 $1800 \mathrm{MHz}$ frequency EMF map

It was determined that similar to the BS-1 the measurements in the $1800 \mathrm{MHz}$ frequency band at the BS-3 base station were more intense. In the measurements made in the $900 \mathrm{MHz}$ band between $20 \mathrm{~m}$ and $500 \mathrm{~m}$ in this region, the maximum value was $6.756 \mathrm{~V} / \mathrm{m}$ and the minimum value was $0.893 \mathrm{~V} / \mathrm{m}$. At the frequency of $1800 \mathrm{MHz}$, these values were measured as $7.236 \mathrm{~V} / \mathrm{m}$ and $0.865 \mathrm{~V} / \mathrm{m}$, respectively (Table 6). When evaluated in terms of compliance with the limit values, it was observed that the limit values determined by ITCI (900MHz: $10.23 \mathrm{~V} / \mathrm{m}, 1800 \mathrm{MHz}: 14.47 \mathrm{~V} / \mathrm{m}$ ) and ICNIRP (900MHz: $41.25 \mathrm{~V} / \mathrm{m}, 1800 \mathrm{MHz}: 58.33 \mathrm{~V} / \mathrm{m}$ ) were not exceeded in both frequency bands (Figure 8). Electromagnetic pollution maps in the region according to frequency bands are given in Figure 9.

\subsection{Detection of Building within the Safety Distance}

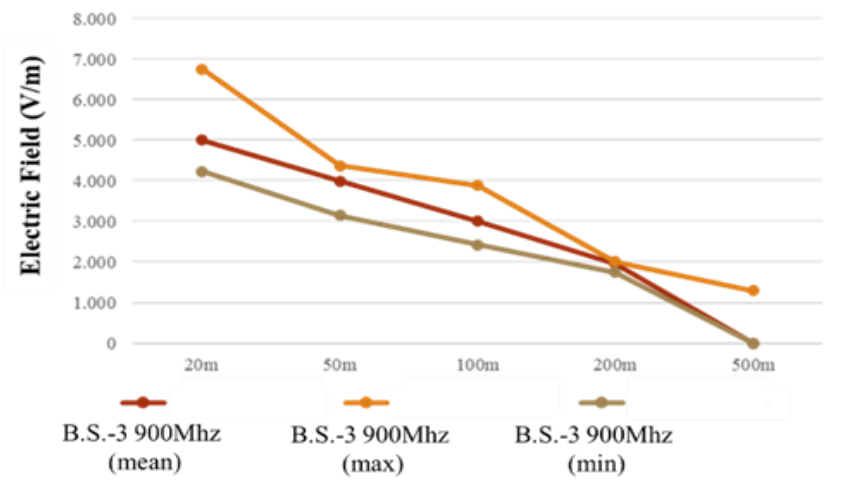

a

One of the main problems in the base stations remaining in the city with the growth of cities is the safety distance issue. In this context, in addition to urban-scale mapping, regional mappings are also important for the determination of this situation. When the base stations discussed in the study were examined, it was determined that residential buildings started after 25 meters from the base station 1, 200 meters from the base station 2, 75 meters from the base station 3, and 350 meters from the base station 4. Based on the security distances determined by the ITCI, for each base station, regional models were created and the buildings in these regions were examined. Accordingly, no construction or building was detected within the safety distance at base stations 1, 2 and 4, while a building (atelier) was detected within the safety distance at base station 3 (Figure 10 a, b, c, d).

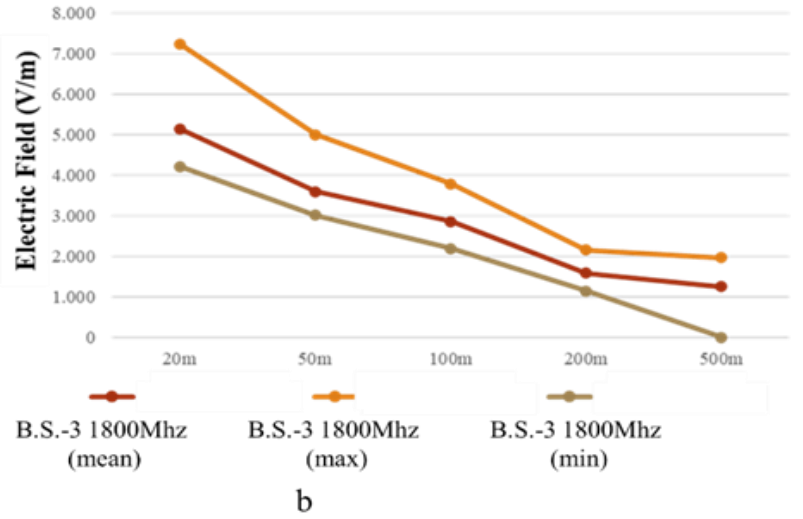

Figure 8. a) BS-1 EF results in $900 \mathrm{MHz}$ frequency b) BS-1 EF results in $1800 \mathrm{MHz}$ frequency

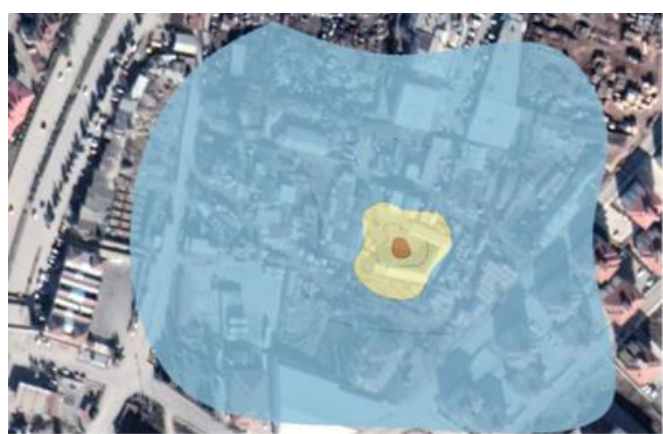

a

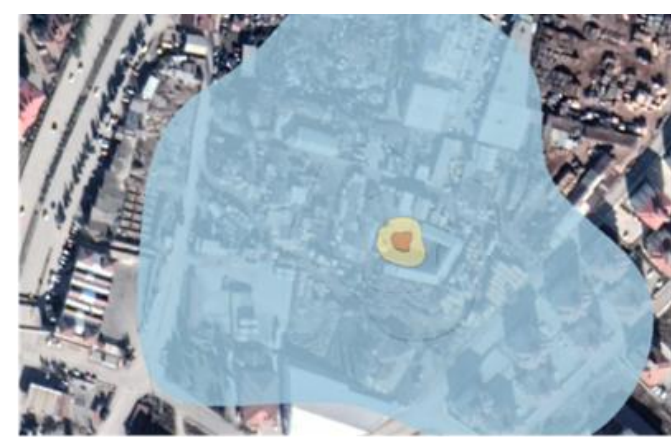

b

Figure 9. a) BS-3 $900 \mathrm{MHz}$ frequency EMF map, b) BS-3 $1800 \mathrm{MHz}$ frequency EMF map 
Table 6. EF results for BS-3 base station between $900 \mathrm{MHz}$ and $1800 \mathrm{MHz}$ frequencies

\begin{tabular}{lllllll}
\hline Frequency & Base station & $20 \mathrm{~m}(\mathrm{~V} / \mathrm{m})$ & $50 \mathrm{~m}(\mathrm{~V} / \mathrm{m})$ & $100 \mathrm{~m}(\mathrm{~V} / \mathrm{m})$ & $200 \mathrm{~m}(\mathrm{~V} / \mathrm{m})$ & $500 \mathrm{~m}(\mathrm{~V} / \mathrm{m})$ \\
\hline \multirow{3}{*}{$900 \mathrm{MHz}(\mathrm{V} / \mathrm{m})$} & BS-3 (max) & 6.756 & 4.369 & 3.891 & 2.003 & 1.289 \\
\cline { 2 - 7 } & BS-3 (mean) & 5.010 & 3.999 & 3.001 & 1.954 & 0.987 \\
\cline { 2 - 7 } & BS-3 (min) & 4.236 & 3.147 & 2.421 & 1.738 & 0.893 \\
\hline \multirow{3}{*}{$1800 \mathrm{MHz}(\mathrm{V} / \mathrm{m})$} & BS-3 (max) & 7.236 & 4.999 & 3.785 & 2.158 & 1.963 \\
\cline { 2 - 7 } & BS-3 (mean) & 5.143 & 3.598 & 2.856 & 1.587 & 1.251 \\
\cline { 2 - 7 } & BS-3 (min) & 4.213 & 3.010 & 2.187 & 1.150 & 0.865 \\
\hline
\end{tabular}

It is seen that there is 1 base station in an area of approximately $2.43 \mathrm{~km}^{2}$, where 12976 people live in the city. However, there is 1 base station in Turkey for every $4.17 \mathrm{~km}^{2}$ area. Compared to the number of base stations per $\mathrm{km}^{2}$ across the country, the number of base stations in Safranbolu is higher.

According to the report published by Information Technologies and Communication Institue in 2010, in a study in which measurements were taken from 242 different points in Karabuk, electric field strength was determined in the range of $0-6 \mathrm{~V} / \mathrm{m}$ [1]. Increasing technological developments and the spread of $3 \mathrm{G}, 4 \mathrm{G}$, and $5 \mathrm{G}$ systems have played an important role in determining a level above these values within the scope of the study. In addition, increasing remote network connections in many sectors due to the COVID-19 pandemic process are likely to have an impact on this data.

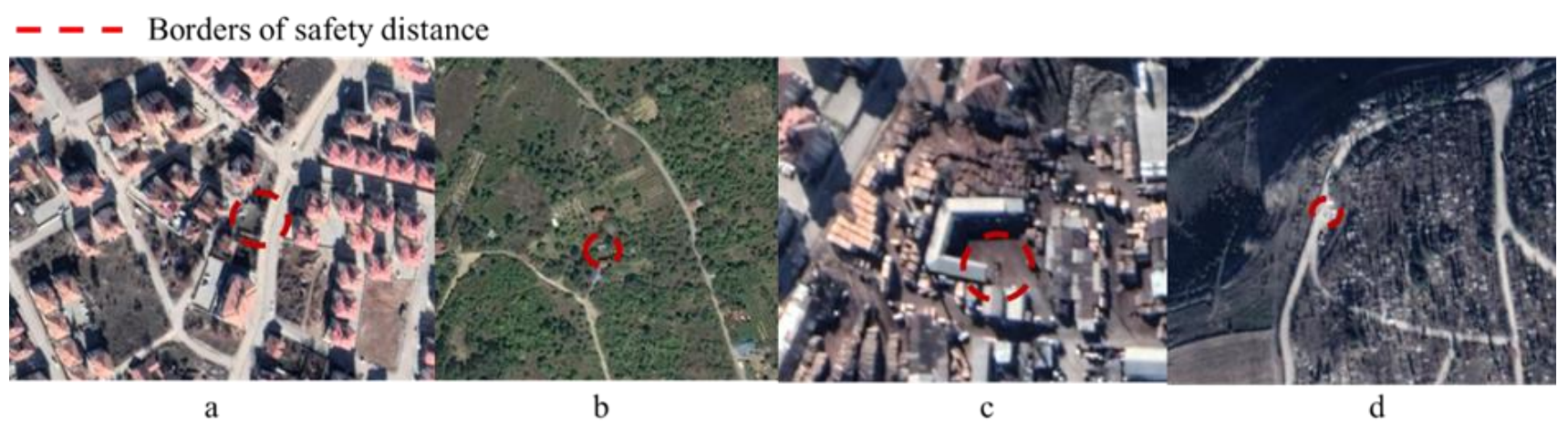

Figure 10. a) B.S.-1 Safety distance, b) B.S.-2 Safety distance, c) B.S.-3 Safety distance, d) B.S.-4 Safety distance

\section{Conclusions}

Within the scope of this study, 4 base stations (BS-1: Esentepe district; BS-2: Bulak district; BS-3: Barış district; BS-4: Babasultan district) were identified in the residential area of Safranbolu city. At all base stations, the highest electromagnetic field values were measured at a distance of $20 \mathrm{~m}$, and the lowest values were measured at a distance of $500 \mathrm{~m}$. This confirms that the electromagnetic field intensity decreases as moving away from the base stations.

In the total measurements, the highest electromagnetic field was detected in the BS-4 base station. It was observed that the measurement results were below the total limit value determined by the ITCI and ICNIRP. In the second stage of the study, measurements were carried out at the frequencies of $900 \mathrm{MHz}$ and $1800 \mathrm{MHz}$ at BS-1 and BS-3 base stations by using the frequency selective method. Considering all the results, it was determined that the electromagnetic field intensity at the frequency of $1800 \mathrm{MHz}$ was higher than that of the frequency of $900 \mathrm{MHz}$. It was found that all measurement values in both frequencies were below the limit values determined by ITCI and ICNIRP.

The danger of electromagnetic pollution originating from base stations is increasing day by day. To prevent this danger, the relevant institutions and organizations must carry out master plans and offer effective solutions by taking into account the settlement areas and safety distances in cities. While making these plans, not only human health should be taken as a criterion, but also other living beings in the region should be considered. In addition, the effect of the electromagnetic field on building biology should also be taken into account, and the base stations should be located away from these areas due to their possible negative effects on historical buildings. Moreover, systems that provide instantaneous detection of possible risk situations by taking measurements with the help of sensors located at certain distances from the base stations and transferring them to a GIS-based data system should be used.

In cases where the specified recommendations are insufficient, it is possible to reach a solution by using textile materials with the ability to absorb electromagnetic radiation, such as polyaniline (PANI), Polythiophene, and conductive dyes. Custom-made textile products and dyes have been developed and put into use with the use of up-todate polymer technologies. Thanks to their special textile structures, these products can provide higher than $99 \%$ protection in different protection efficiency areas at different frequency ranges.

In addition, electro-conductive paints have a solid content consisting of adhesives such as acrylic, acrylic urethane resin mixed with electrically conductive filler such as nickel, copper, silver or graphite powder. The shielding capacity of electro-conductive paint is directly related to the thickness of the paint. For this reason, it is important to apply the paint thickly and uniformly [56-57]. These paints provide an effective shielding against electromagnetic fields when applied correctly. 
For future studies, it is considered to determine the continuous electromagnetic field with longer-term measurements and to determine the relationship between human disease symptoms and electromagnetic field.

\section{Conflict of Interest Statement}

The authors declare no conflict of interest.

\section{References}

[1] ITCI, Türkiye elektromanyetik alan maruziyet raporu (in Turkish), Prepared by: İnan Güler, Tamer Çetin, A. Rıza Özdemir, Nedim Uçar. 2010.

[2] J. Gonzalez-Rubio, E. Arribas, R. Ramirez-Vazquez, A. Najera, Radiofrequency electromagnetic fields and some cancers of unknown etiology: An ecological study, Science the Total Environment 599 (2017) 834-843.

[3] M. Gallastegi, A. Huss, L. Santa-Marina, J.J. Aurrekoetxea, M. Guxens, L. Ellen Birks, J. Ibarluzea, D. Guerra, M. Röösli, A. Jimenez-Zabala, Children's exposure assessment of radiofrequency fields: Comparison between spot and personal measurements, Environment. International. 118 (2018) 6069.

[4] C. Regrain, J. Caudeville, R. de Seze, M. Guedda, A. Chobineh, P. de Doncker, L. Petrillo, E. Chiaramello, M. Parazzini, W. Joseph, S. Aerts, A. Huss, J. Wiart, Design of an integrated platform for mapping residential exposure to $\mathrm{rf}$-emf sources, Int. J. Environ. Res. Public Health 17 (2020) 5339.

[5] Ç. Güler, Z. Çobanoğlu, Elektromanyetik Radyasyon(in Turkish), T.C Sağlık Bakanlığı Sağlık Hizmetleri Genel Müdürlüğü, Turkey, Ankara, 1994.

[6] European Commission, Health and Electromagnetic field, Research Directorate-General - European Communities. 2005.

[7] E. van Deventer, E. van Rongen, R. Saunders, WHO research agenda for radiofrequency fields, Bioelectromagnetics 32 (2011) 417-421.

[8] S. Martin, P. De Giudici, J.C. Genier, E. Cassagne, J.F. Doré, P. Ducimetière, A.S. Evrard, T. Letertre, C. Ségala, Health disturbances and exposure to radiofrequency electromagnetic fields from mobile-phone base stations in French urban areas, Environmental Research, 193 (2021) 110583.

[9] A.B. Olorunsola, O.M. Ikumapayi, B.I. Oladapo, A.O. Alimi, A.O. Adeoye, Temporal variation of exposure from radiofrequency electromagnetic fields around mobile communication base stations, Scientific African 12 (2021) e00724.

[10] D.J. Griffiths, Elektromanyetik teori (in Turkish), ARTe Güven Yayınları, Turkey, İstanbul, 1996.

[11] Balmori, Electromagnetic pollution from phone masts. Effects on Wildlife, Pathophysiology 16 (2009) 191-199.

[12] M. Ruediger, M. Alastair, B. Juergen, V. Paolo, V. Bernard, Exposure to static and low frequency electromagnetic fields, biological effects and health consequences (0-100Khz). Review of the scientific evidence on dosimetry, biological effects, epidemiological observations, and health consequences concerning exposure to static and low frequency electromagnetic fields $(0-100 \mathrm{kHz})$, International Commission on Non-Ionizing Radiation Protection (ICNIRP), Report Number: ICNIRP-13-2003.

[13] H.P. Hutter, H. Moshammer, P. Wallner, M. Kundi, Subjective symptoms, sleeping problems, and cognitive performance in subjects living near mobile phone base stations, Occupation Environment Medicine 63 (2006) 307-313.

[14] C.M. Krause, L. Sillanmaki, M. Koivisto, A. Haggqvist, C. Saarela, A. Revonsuo, M. Laine, H. Hamalainen, Effects of electromagnetic field emitted by cellular telephones on the EEG during a memory task, NeuroReport 11 (2000) 761-764.
[15] G. Abdel-Rassoul, O. Abou El-Fateh, M. Abou Salem, A. Michael, F. Farahat, M. El-Batanouny, E. Salem, Neurobehavioral effects among inhabitants around mobile phone base stations, Neurotoxicology 28 (2007) 434-440.

[16] C.Y. Li, G. Thériault, R.S. Lin, Residental exposure to 60Hertz magnetic fields and adult cancers in Taiwan, Epidemology 8 (1997) 25-30.

[17] G.M. Lee, R. Neutra, L. Hristova, M. Yost, R. Hiatt, A nested case-control study of residential and personal magnetic field measures and miscarriages, Epidemiology 13 (2002) 21-31.

[18] C. Qiu, L. Fratiglioni, A. Karp, B. Winblad, T. Bellander, Occupational exposure to electromagnetic fields and risk of Alzheimer's disease, Epidemiology 15 (2004) 687-694.

[19] G.C. Windham, A.M. Osorio, Female reproductive toxicology, Current Occupational and Environmental Medicine 3rd ed., J. LaDou Ed., Lange Medical Boks/McGraw-Hill, USA, (2004) 397-413.

[20] G. Draper, T. Vincent, M.E. Kroll, J. Swanson, Chilhood cancer in relation to distance from high voltage Power lines in England and Wales: a case-control study, BMJ 330 (2005) 1290-1293.

[21] L. Klaeboe, K.G. Blaasaas, T. Haldorsen, T. Tynes, Residential and occupational exposure to $50 \mathrm{~Hz}$ magnetic fields and brain tumors in Norway: A population-based study, International Journal of Cancer 115 (2005) 137- 141.

[22] S. Milham, Dirty electricity: Electrification and the diseases of civilization, Second Edition, Bloomington, IN, USA: iUniverse, 2012.

[23] Zothansiama, M. Zosangzuali, M. Lalramdinpuii, G.C. Jagetia, Impact of radiofrequency radiation on DNA damage and antioxidants in peripheral blood lymphocytes of humans residing in the vicinity of mobile phone base stations, Electromagnetic. Biology Medicine 36 (2017) 295-305.

[24] D. Belpomme, L. Hardell, I. Belyaev, E. Burgio, O.D. Carpenter, Thermal and non-thermal health effects of low intensity non-ionizing radiation: An international perspective, Environmental Pollution 242 (2018) 643-58.

[25] F.T. Ulaby, Fundamentals of Applied Electromagnetics, Englewood Cliffs, NJ, Prentice Hall, 2001.

[26] L. Moulton Howe, Growing concern about electromagnetic pollution and cell phones, (2008).

[27] Ç. Güler, A. Vaizoğlu, Çevre sağlığı: İyonlaştıran ve iyonlaştırmayan radyasyon (in Turkish), Halk Sağlığı Temel Bilgiler, 2. Baskı, Hacettepe Üniversitesi Yayınları, Turkey, Ankara, 2012.

[28] O. Çerezci, Elektromanyetik kirlilik (in Turkish), Elektromanyetik alan ve sağlık etkileri, Cilt 1, Özsan Matbaacılık, Bursa, 2012.

[29] F. Deruelle, The different sources of electromagnetic fields: dangers are not limited to physical health, Electromagnetic Biology and Medicine 39 (2020) 166-175.

[30] T. Karadağ, A.Özdemir, T. Abbasov, Seçilmiş bir pilot bölgede uzun süreli ve sürekli elektromanyetik kirlilik seviyelerinin ölçülmesi ve haritalanması (in Turkish), Gazi Üniversitesi Fen Bilimleri Dergisi Part C: Tasarım ve Teknoloji 2 (2014) 239-246.

[31] A.Mousa, Electromagnetic radiation measurements and safety issues same cellular base stations in Nablus, Journal of Engineering Science and Technology Review 4 (2011) 35-42.

[32] T. Karadağ, M. Yüceer, T. Abbasov, A Large-scale measurement, analysis and modelling of electromagnetic radiation levels in the vicinity of GSM/UMTS base stations in an urban area, Radiation Protection Dosimetry 168 (2015) 114.

[33] W. Joseph, G. Vermeeren, L. Verloock, M.M. Heredia, L. Martens, Characterization of personal RF electromagnetic field exposure and actual absorption for the general public, Health Physics 95 (2008) 317-330. 
[34] G. Thuróczy, F. Molnár, G. Jánossy, N. Nagy, G. Kubinyi, J. Bakos, J. Szabo, Personal RF exposimetry in urban area, Annals of Telecommunications 63 (2008) 87-96.

[35] J.F. Viel, E. Cardis, M. Moissonnier, R. de Seze, M. Hours, Radiofrequency exposure in the French general population: band, time, location and activity variability, Environment International 35 (2009) 1150-1154.

[36] P. Frei, E. Mohler, G. Neubauer, G. Theis, A. Bürgi, J. Fröhlich, C. Braun-Fahrländer, J. Bolte, M. Egger, M. Röösli, Temporal and spatial variability of personal exposure to radio frequency electromagnetic fields, Environmental Research 109 (2009) 779-785.

[37] G. Berg-Beckhoff, M. Blettner, B. Kowall, J. Breckenkamp, B. Schlehofer, S. Schmiedel, C. Bornkessel, U. Reis, P. Potthoff, J. Schüz, Mobile phone base stations and adverse health effects: phase 2 of a crosssectional study with measured radio frequency electromagnetic fields, Occupational and Environmental Medicine 66 (2009) 118-123.

[38] W. Joseph, L. Verloock, E. Tanghe, L. Martens, In-situ measurement procedures for temporal RF electromagnetic field exposure of the general public, Health Physics 96 (2010) 529-542.

[39] J.F. Bolte, T. Eikelboom, Personal radiofrequency electromagnetic field measurements in the Netherlands: Exposure level and variability for everyday activities, times of day and types of area, Environment İnternational 48 (2012) 133-142.

[40] D. Urbinello, W. Joseph, L. Verloock, L. Martens, M. Röösli, Temporal trends of radio-frequency electromagnetic field (RF-EMF) exposure in everyday environments across European cities, Environmental Research 134 (2014) 134142.

[41] R. Fernández-García, I. Gil, Measurement of the environmental broadband electromagnetic waves in a mid-size European city, Environmental Research 158 (2017) 768-772.

[42] D.K. Li, R. Odouli, S. Wi, T. Janevic, I. Golditch, T. Dan Bracken, R. Senior, R. Rankin, R. İriye, A Population-based prospective cohort study of personal exposure to magnetic fields during pregnancy and the risk of miscarriage, Epidemiology 13 (2002) 9-20.

[43] M. Şahin, A. Nilüfer, Y. Karan, Selective radiation measurement for safety evaluation on base stations, Gazi University Journal of Science 26 (2013) 73-83.

[44] S.N. Hazmin, A.R.S.N. Dianah, R. Umar, A.N. Dagang, M.K.A. Kamarudin, H. Jaafar, Non-ionizing radiation exposure: electric field strength measurement around selected base stations in Kuala Nerus, Journal of Fundamental and Applied Sciences 10 (2018) 52-65.

[45] S. Adda, T. Aureli, S. D'elia, D. Franci, E. Grillo, M.D. Migliore, S. Pavoncello, F. Schettino, R. Suman, A theoretical and experimental investigation on the measurement of the electromagnetic field level radiated by $5 \mathrm{G}$ base stations, IEEE Access 8 (2020).101448-101463.

[46] J.S. Kazaure, U.O. Matthew, Electromagnetic Radiation (EMR) and Human Health: A Study on the health effect of EMR from GSM base stations in North-Western Nigeria, American Journal of Electrical and Computer Engineering 5 (2021) 14-24.

[47] R. Sánchez-Montero, C. Alén-Cordero, P.L. López-Espí, J.M. Rigelsford, F. Aguilera-Benavente, J. Alpuente-Hermosilla, Long term variations measurement of electromagnetic field exposures in Alcalá de Henares (Spain), Science of The Total Environment 598 (2017) 657-668.

[48] R.A. Badru, K.P. Olorunyomi, A.O. Salau, O.İ. Akinwale, J.N. Alwadood, A.N. Atijosan, Evaluation of electric field pollution from $132 \mathrm{kVA}$ power transmission lines to proximity of infrastructures in Ibadan, Nigeria, Bilge International Journal of Science and Technology Research 1 (2017) 46-58.
[49] C. Tang, C. Yang, R.S. Cai, H. Ye, L. Duan, Z. Zhang, Z. Shi, K. Lin, J. Song, X. Huang, H. Zhang, J. Yang, P. Cai, Analysis of the relationship between electromagnetic radiation characteristics and urban functions in highly populated urban areas, Science of the Total Environment 654 (2019) 535-540.

[50] R. Ramirez-Vazquez, S. Arabasi, H. Al-Taani, S. Sbeih, J. Gonzalez-Rubio, I. Escobar, E. Arribas, Georeferencing of personal exposure to radiofrequency electromagnetic fields from wi-fi in a university area, International Journal of Environmental Research and Public Health 17 (2020) 1898.

[51] Z. Ming, L. Xiang, Regional risk assessment for urban major hazards based on GIS geoprocessing to improve public safety, Safety Science 87 (2016) 18-24.

[52] P. Månsson, Uncommon sense: A review of challenges and opportunities for aggregating disaster risk information, International Journal of Disaster Risk Reduction 40 (2019) 101149.

[53] M. Zhao, X. Liu, Z. Sun, Development of decision support tool for clustering urban regional risk based on R-ArcGIS Bridge, Applied Soft Computing 110 (2021) 107621.

[54] S. Nasehi, S. Karimi, H. Jafari, Application of fuzzy GIS and ANP for wind power plant site selection in East Azerbaijan Province of Iran, Computational Research Progress in Applied Science \& Engineering 2 (2016) 116-124.

[55] M. Ghorbanzadeh, M. Effati, M. Gilanifar, E.E. Ozguven, Subway station site selection using GIS-based multi-criteria decision-making: A case study in a developing country. Comput. Res. Prog. Appl. Sci. Eng. 6 (2020) 60-69.

[56] C. Tamam, M. Evrensel, Y. Tamam, Elektromanyetik alanların insan sağlığı üzerindeki etkileri (in Turkish)., Bilimsel Tamamlayıcı Tıp Regülasyon ve Nöral Terapi Dergisi 10 (2016) 19-25.

[57] R. Yılmaz, Elektromanyetik kalkanlama özelliği olan malzemeler (in Turkish) . Ejovoc (Electronic Journal of Vocational Colleges) 4 (2014) 136-150 . Retrieved from 